\title{
Determination of alfalfa leaf area by non-destructive method
}

\author{
Silvano Bianco ${ }^{1}$, Leonardo Bianco de Carvalho $^{2^{*}}$, Matheus Saraiva Bianco ${ }^{3}$ \\ ${ }^{1}$ Professor at Faculty of Agrarian and Veterinarian Sciences of the Sao Paulo State University, Jaboticabal, Brazil, sbianco@fcav.unesp.br. \\ ${ }^{2}$ Postdoc at Faculty of Agrarian and Veterinarian Sciences of the Sao Paulo State University, Jaboticabal, Brazil, agrolbcarvalho@gmail.com. \\ ${ }^{3}$ Master student at Faculty of Agrarian and Veterinarian Sciences of the Sao Paulo State University, Jaboticabal, Brazil, \\ matbianco2004@yahoo.com.br. \\ ${ }^{*}$ Author for correspondence
}

\begin{abstract}
The knowledge of plant leaf area is important to evaluate the vegetal growth. The objective of this research was to determine a mathematical equation to estimate successfully alfalfa (Medicago sativa) leaf area by measuring linear dimensions of the leaf blade of the plant leaflets. The leaves were collected from cultivar 'Crioula' cropped at field conditions in Jaboticabal, SP, Brazil. The leaflets length, width and leaf blade area were determined electronically. Linear, geometric and exponential equations were tested, considering the length and width separately and the length $x$ width relation. The lateral leaflets showed similar dimensions and they were different to the central leaflet. So, it was opted to analyze the lateral leaflets together. All equations described satisfactorily the alfalfa leaf area, but it was opted for the linear equation passing through the origin due to its better practical application, showing high significance and normal distribution of residuals. This equation was validated with coefficient of correlation of 0.96 , showing high significance $(P<0.01)$. The alfalfa leaf area can be estimated by the equation $L A=0,691156 \times \mathrm{LWct}+0,3652754 \times \mathrm{LWIt}$, where LWct is the central leaflet length $\times$ width and LWlt is the sum of the left and right lateral leaflets length $\times$ width.
\end{abstract}

Keywords: Medicago sativa, biometry, mathematical equation, plant growth.

\section{Introduction}

Determination of leaf area is important in different areas of researching with plants (Pedro Junior et al. 1986). Knowledge of leaf area is fundamental in studies of plant growth because it is one of the most important characteristics in the evaluation of vegetal growth (Portela 1999, Bhatt and Chanda 2003, Bianco et al. 2008a,b, 2009). Leaf area estimation can be performed by different methods, so that nondestructive methods are more interesting to be used because there is no need to collect the plant, or parts of plants, for measurement. Among non-destructive methods for leaf area estimation, the determination of mathematical equations relating leaf linear dimensions is the most used methods (Bianco et al. 2002, 2004, 2007a,b, 2008a,b, 2009, Duarte et al. 2009).

Leaf area estimation by mathematical equations have been used with high precision, being a simple, rapid and non-destructive method that has became important to evaluate plant growth in field conditions (Bianco et al. 2007a,b). Regression equations, relating measured leaf area with linear dimensions of leaves, have been used successfully to estimate leaf area of crops like strawberry (Strik and Proctor 1985, Pires et al. 1999), vine (Pedro Júnior et al. 1986), corn (Pereira 1987), squash (Silva et al. 1998), garlic (Portela 1999), bean (Bhatt and Chanda 2003, Queiroga et al. 2003), coconut (Souza et al. 2005), mango (Araújo et al. 2005), cotton (Monteiro et al. 2005, Alves et al. 2009), cherry (Cittadini and Peri 2006), potato (Busato et al. 2009), papaya (Posse et al. 2009), among others. In this sense, there is no information with respect of an equation to estimate alfalfa (Medicago sativa) leaf area, perennial leguminous cropped as an important forage in Brazil (Favero et al. 2008, Perez and
Dall'Agnol 2009).

The objective of this research was to determine a mathematical equation to estimate successfully alfalfa leaf area by measuring linear dimensions of the leaf blade of the plant leaflets.

\section{Material and methods}

Plants of alfalfa cultivar 'Crioula' were cropped in

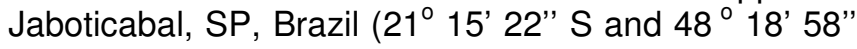
$W G)$ in 2009. One hundred healthy leaves were collected from different positions in many alfalfa plants growing in field conditions. In the lab, those leaves were separated into leaflets (central, left and right) which were measured according to the length of leaf blade throughout principal vein (L), the maximum width of leaf blade (W) and the leaf area of the leaf blade (LA), using portable area meter (LiCor, LI-3000A, USA).

Data of length, width and leaf area of the three leaflets were submitted to ANOVA test and the means are compared by Tukey test at $5 \%$ of probability, using software Sisvar (UFV, version 5.1, Brazil), to know if there are equality among the leaflets. Being similar, only one equation could be used to estimate the leaf area of these leaflets.

Alfalfa leaf area $(Y)$ estimation was performed by regression analysis by the models linear $(Y=b X$ and $\mathrm{Y}=\mathrm{a}+\mathrm{bX}$, where $\mathrm{X}$ was $\mathrm{L}, \mathrm{W}$ or $\mathrm{L} \times \mathrm{W})$, geometric $\left(Y=a X^{b}\right.$ where $X$ was $L$ or $\left.W\right)$ and exponential $\left(Y=a b^{X}\right.$ where $X$ was $L$ or $W$ ), being $a$ and $b$ equation parameters, considering the central leaflet and the sum of the lateral leaflets, using software Statistica (StatSoft, version 6.0, USA).

After the selection of one of the models according to the results of the ANOVA of the regression and the 
facility of using in field conditions, residuals of the selected regression model was submitted to ShapiroWilk's normality test $(P=0.05)$, being the residual frequencies showed by histograms, using software Statistica (StatSoft, version 6.0, USA).

For validation of the regression model, 30 new leaves, of the same alfalfa cultivar cropped in 2010 at the same field, were collected. The same measurements were performed in these leaves, L, W and LA. The leaf area was determined according to the equation previously determined. Following, SpearmanRank's linear correlation test $(P=0.05)$ were performed between the measured leaf area and the estimated leaf area of those new leaves, using software Statistica (StatSoft, version 6.0, USA), being the results also graphically exposed.

\section{Results and discussion}

Leaf blade length, width and area of central leaflets were different of those ones of the lateral leaflets (left and right leaflets), but both left and right lateral leaflets showed similar length, width and leaf blade area (Table 1). This indicated that at least two equations are needed to estimate alfalfa leaf area, one of them for central leaflets and another one for the sum of lateral leaflets. Similar procedure must be used for Merremia aegyptia leaf area estimation (Bianco et al. 2009).

Table 1. Average values of length (L), maximum width $(\mathrm{W})$ and leaf blade area (LA) of leaflets of alfalfa cultivar 'Crioula'. Jaboticabal, Brazil, 2011.

\begin{tabular}{lccc}
\hline Leaflet & $\mathrm{L}$ & $\mathrm{W}$ & $\mathrm{LA}$ \\
& $\left(10^{-1} \mathrm{dm}\right)$ & $\left(10^{-1} \mathrm{dm}\right)$ & $\left(10^{-2} \mathrm{dm}^{2}\right)$ \\
\hline Central & $1.75 \mathrm{~A}$ & $0.97 \mathrm{~A}$ & $1.21 \mathrm{~A}$ \\
Left & $1.60 \mathrm{~B}$ & $0.86 \mathrm{~B}$ & $1.03 \mathrm{~B}$ \\
Right & $1.57 \mathrm{~B}$ & $0.87 \mathrm{~B}$ & $1.03 \mathrm{~B}$ \\
\hline $\mathrm{F}$ & $12.71^{\star *}$ & $15.08^{\star *}$ & $12.32^{\star *}$ \\
CV $(\%)$ & 16.70 & 17.55 & 26.83 \\
LSD & 0.09 & 0.05 & 0.10 \\
\hline
\end{tabular}

** indicates significant different by $1 \%$ according to $F$ test; average values followed by the same letter in the columns are not different by $5 \%$ of probability according to Tukey test.

For both central and lateral leaflets, any tested regression models were highly significant $(P<0.01)$, but some of them showed higher coefficient of determination and $\mathrm{F}$ value, such as the linear models adjusted to length and width product (Table 2). However, the linear model whose linear coefficient is 0

Table 2. Estimate equations of leaf blade area of the central leaflet and lateral leaflets of alfalfa cultivar 'Crioula', equation determination coefficient $\left(R^{2}\right), F$ value and $p$ value of the regression analysis. Jaboticabal, Brazil, 2011.

\begin{tabular}{|c|c|c|c|c|c|}
\hline $\mathrm{X}^{/ 1}$ & Type & Leaf Area Equation & $\mathrm{R}^{2}$ & $\mathrm{~F}$ & $p$ \\
\hline \multicolumn{6}{|c|}{ Central Leaflet } \\
\hline L & Linear & $0.3050082+0.8622979 \times C$ & 0.62 & $1,820.48$ & $<0.01$ \\
\hline W & Linear & $0.4136304+1.66759 \times \mathrm{L}$ & 0.67 & $2,121.01$ & $<0.01$ \\
\hline LW & Linear & $0.1550595+0.6085339 \times C L$ & 0.88 & $5,428.93$ & $<0.01$ \\
\hline $\operatorname{LW}(0,0)$ & Linear & $0.691156 \times C L$ & 0.88 & $9,487.19$ & $<0.01$ \\
\hline L & Geometric & $0.6089241 \times C^{1.187316}$ & 0.64 & $1,845.01$ & $<0.01$ \\
\hline W & Geometric & $1.229925 \times L^{1.279602}$ & 0.66 & $2,186.55$ & $<0.01$ \\
\hline L & Exponential & $0.3291422 \times 2.055502^{C}$ & 0.66 & $1,867.45$ & $<0.01$ \\
\hline W & Exponential & $0.3118902 \times 3.878327^{L}$ & 0.67 & $2,294.29$ & $<0.01$ \\
\hline \multicolumn{6}{|c|}{ Lateral Leaflets } \\
\hline L & Linear & $-0.724271+0.8788917 \times C$ & 0.80 & $2,108.71$ & $<0.01$ \\
\hline W & Linear & $-0.667413+1.567403 \times \mathrm{L}$ & 0.86 & $3,158.77$ & $<0.01$ \\
\hline LW & Linear & $0.2778895+0.3191958 \times C L$ & 0.96 & $10,157.55$ & $<0.01$ \\
\hline $\operatorname{LW}(0,0)$ & Linear & $0.3652754 \times C L$ & 0.96 & $16,441.11$ & $<0.01$ \\
\hline L & Geometric & $0.4695423 \times C^{1.268286}$ & 0.80 & $2,165.15$ & $<0.01$ \\
\hline W & Geometric & $1.007911 \times L^{1.265459}$ & 0.85 & $3,230.50$ & $<0.01$ \\
\hline L & Exponential & $0.5333871 \times 1.51691^{\mathrm{C}}$ & 0.85 & $2,264.17$ & $<0.01$ \\
\hline W & Exponential & $0.5670192 \times 2.061497^{L}$ & 0.85 & $3,192.05$ & $<0.01$ \\
\hline
\end{tabular}

${ }^{\pi}$ Linear measurements: length (L) and maximum width (W) of the leaf blade of the central leaflet and the sum of $L$ and $W$ of lateral leaflets.

showed higher $\mathrm{F}$ values for both central and lateral leaflets. In addition, residuals of the regression analysis were normally distributed for both central and lateral leaflets $(P>0.05)$ (Figure 1). This indicates that the linear model whose linear coefficient is 0 could be selected for satisfactory estimation of alfalfa leaf area. Strik and Proctor (1985), Pires et al. (1999), Bianco et al. (2007a,b, 2008a,b), Duarte et al. (2009), and others, testing different mathematical models for leaf area estimation, concluded that the linear models are more adequated to estimate plant leaf area. In addition, Bianco et al. (2007a,b, 2008a,b, 2009) and
Duarte et al. (2009) affirmed that this linear model is of more simple and better practical use for leaf area estimation.

The relation between observed and predicted values of alfalfa leaf area, tested for validation of the model (Partelli et al. 2007), showed high coefficient of correlation $(R=0.96)$, being also highly significant $(P<$ 0.01 ) (Figure 2). This indicates that the selected linear model is adequated to estimate the alfalfa leaf area. So, according to our results, researchers can use the selected linear model to estimate the leaf area of alfalfa plants in their investigations with high accuracy. 

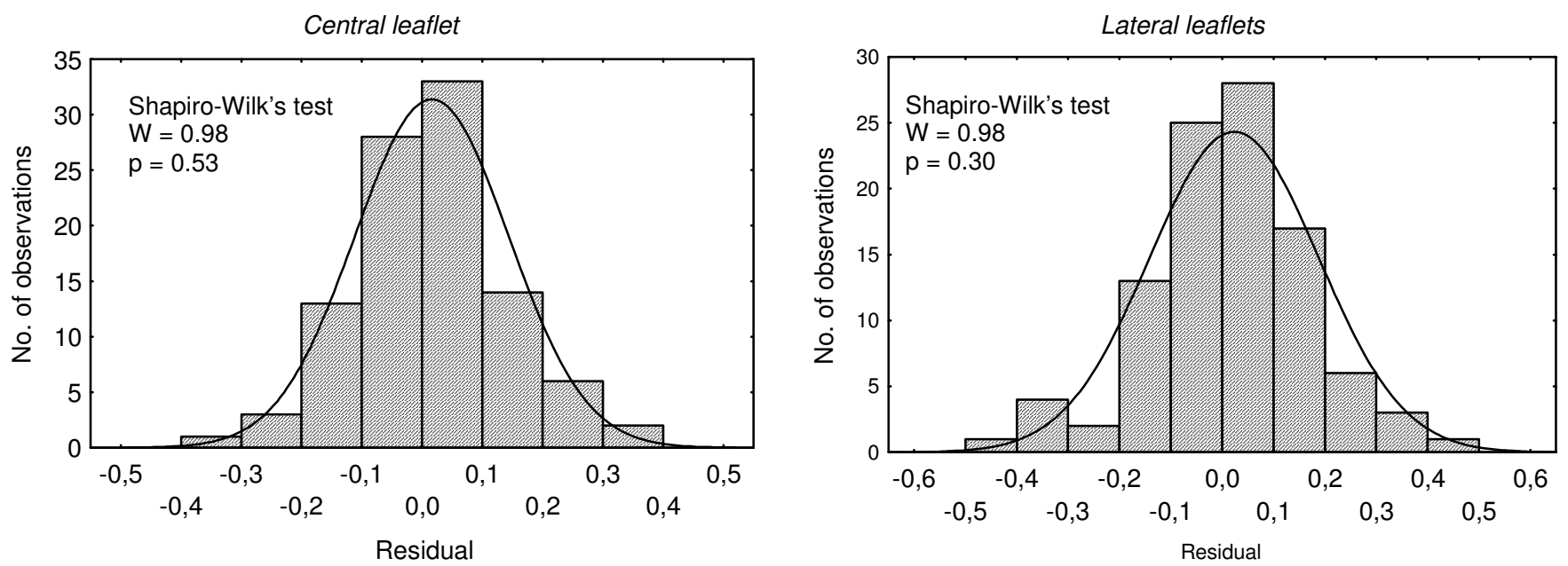

Figure 1. Distribution of residuals of the linear regression analysis of central and lateral leaflets of alfalfa cultivar 'Crioula' and respective Shapiro-Wilk's test for normality analysis. Jaboticabal, Brazil, 2011.

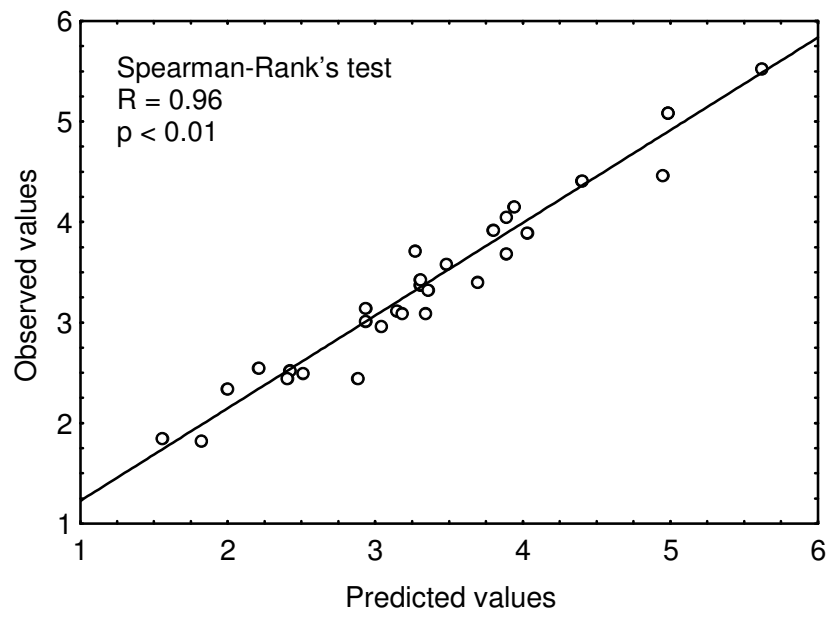

Figure 2. Relation between observed and predicted values by linear regression of the leaf area of alfalfa cultivar 'Crioula' and respective Spearman-Rank test for analysis of correlation. Jaboticabal, Brazil, 2011.

\section{Conclusions}

According to the statistical procedures, the leaf area of alfalfa cultivar 'Crioula' can be estimated by the equation $\mathrm{Y}=0.691156 \times \mathrm{LWcl}+0.3652754 \times \mathrm{LWII}$, where LWcl is the product of length $\times$ width of central leaflet and LWII is the product of length $\times$ width of the sum of left and right lateral leaflets.

\section{References}

Alves WWA, Azevedo CAV, Dantas Neto J, Lima VLA. 2009. Foliar area of the cotton plant irrigated with it wastewater fertilized with nitrogen and phosphorus. Rev Verde 4:41-46.

Araújo ECE, Santos EP, Prado CHBA. 2005. Leaf area estimation of mango (Mangifera indica cvs Tommy Atkins and Haden, using linear dimensions. Rev Bras Frutic 27:308-309.

Bhatt M, Chanda SV. 2003. Prediction of leaf area in Phaseolus vulgaris by non-destructive method. Bulgarian J Plant Physiol 29:96-100.

Bianco S, Bianco MS, Carvalho LB. 2007a. Leaf area estimation of Leonotis nepetifolia (L.) W.T. Aiton using leaf blade linear dimensions. Ci Cult 2:27-31.
Bianco S, Bianco MS, Pavani M.CMD, Duarte DJ. 2007b. Leaf area estimate in Ipomoea hederifolia and Ipomoea nil Roth. Using linear dimensions of the leaf blade. Planta Daninha 25:325-329.

Bianco S, Bianco MS, Carvalho LB. 2008a. Estimate of Ageratum conyzoides leaf area using leaf blade linear measurements. Acta Sci Agron 30:519-523.

Bianco S, Carvalho LB, Bianco MS. 2008b. Estimate of Sida cordifolia and Sida rhombifolia leaf area using leaf blade linear dimensions. Planta Daninha 26:807813.

Bianco S, Carvalho LB, Panosso, AR, Bianco MS. 2009. Determination of the leaf area of Merremia aegyptia. Planta Daninha 27:941-945.

Bianco S, Pitelli RA, Carvalho LB. 2002. Leaf area estimate of Cissampelos glaberrima using linear dimensions of the leaf blade. Planta Daninha 20:353356.

Bianco S, Pitelli RA, Carvalho LB. 2004. Leaf area estimation in Tridax procumbens using linear dimensions of the leaf blade. Planta Daninha 22:247250.

Busato C, Fontes PCR, Braun H, Coelho FS, Silva MC, Oliveira LS. 2009. Evaluation of the leaf area Cupido cultivar. Hort Bras 27:3570-3573.

Cittadini EC, Peri PL. 2006. Estimation of leaf area in sweet cherry using a non-destructive method. Rev Invest Agropec 35:143-150.

Duarte DJ, Bianco S, Carvalho LB, Panosso AR. 2009. Euphorbia heterophylla leaf area estimate. Planta Daninha 27:527-531.

Fávero D, Heffer-Basso, SM, Dall'Agnol M, Seco, D. 2008. Performance of alfalfa populations under defoliation. Rev Bras Zootec 37:589-595.

Monteiro JEBA, Sentelhas PC, Chiavegato EJ, Guiselini C, Santiago AV, Prela A. 2005. Cotton leaf area estimates on leaf dimensions and dry mass methods. Bragantia 64:15-24.

Partelli FL, Vieira HD, Viana, AP. 2007. Estimative of black pepper leaf area with basis on the leaf blade linear dimension. Ci Rural 37:1458-1461.

Pedro Júnior MJ, Ribeiro IJA, Martins FP. 1986. Rapid estimation of leaf area in grape, cv. Niagara rosada. Bragantia 45:199-204. 
Pereira AR. 1987. Estimating leaf area in cotton crops. Bragantia 46:147-150.

Perez NB, Dall'Agnol. 2009. Morphological characteristics of alfalfa plants in relation to the grazing aptitude. Rev Bras Zootec 38:418-421.

Pires RCM, Folegatti MV, Passos FA. 1999. Estimate of Five strawberry cultivars leaf area. Hort Bras 17:86-90.

Portela JA. 1999. Models to estimate leaf area of onion (Allium sativum L.) 'blanco' clonal type.. Hort Arg 18:5-10.

Posse RP, Souza EF, Bernardo S, Pereira MG, Gottardo RD. 2009. Total leaf area of papaya trees estimated by a nondestructive method. Sci Agric 66:462-466.

Queiroga JL, Romano EDU, Souza JRP, Miglioranza E. 2003. Model to estimate leaf area of snap bean. Hort Bras 21:64-68.

Silva NF, Ferreira FA, Fontes PCR, Cardoso AA. 1998. Models to estimate the leaf area of squash by linear measurements. Ceres 45:287-291.

Souza EF, Araújo MC, Posse RP, Detmann E, Bernardo S, Berbert PA, Santos PA. 2005. Estimating the total leaf area of the green dwarf coconut tree (Cocos nucifera L.). Sci Agric 62:597600.

Strik BC, Proctor JTA. 1985. Estimating the area of trifoliate and unequally imparipinnate leaves of strawberry. HortSci 20:1072-1074. 